\title{
TRAIL/Apo2L Ligands Induce Apoptosis in Malignant Rhabdoid Tumor Cell Lines
}

\author{
SHINOBU YOSHIDA, TSUTOMU NARITA, SHIGEKI KOSHIDA, SHIGERU OHTA, AND \\ YOSHIHIRO TAKEUCHI
}

\author{
Department of Pediatrics, Shiga University of Medical Science, Tsukinowa-cho, Seta, Shiga 520-2192, \\ Japan
}

\section{ABSTRACT}

\begin{abstract}
Tumor necrosis factor-related apoptosis-inducing ligand (TRAIL/Apo2L) is a potent inducer of apoptosis in various cancer cells, whereas normal cells are not sensitive to TRAILmediated apoptosis. Four TRAIL/Apo2L receptors (DR4, DR5, DcR1, and DcR2) have been identified. DR4 and DR5 have a death domain, whereas DcR1 and DcR2 are called decoy receptors because of their incomplete or lack of a death domain. Malignant rhabdoid tumor (MRT) is an aggressive neoplasm showing a poor prognosis because of its resistance to chemotherapeutic agents. In this study, we examined whether TRAIL could induce apoptotic cell death in MRT cell lines. We found that although half of the MRT cell lines examined were sensitive to TRAIL/Apo2L, Western blot analysis revealed that the expression of DcR2 was low in TRAIL-sensitive MRT cells. We examined the effect of doxorubicin on the expression levels of TRAIL receptors and its enhancement on the susceptibility of MRT cell lines to TRAIL. Western blot and flow cytometric analyses revealed that doxorubicin significantly increased the expression of DR5, and somewhat up-regulated the expression of
\end{abstract}

DR4 and DcR2. Moreover, doxorubicin, NF- $\kappa \mathrm{B}$ inhibitor (SN50), and PI3-kinase/Akt inhibitor (wortmannin, LY294002) enhanced the susceptibility of MRT cell lines to TRAIL/Apo2Linduced apoptosis. These results suggest that TRAIL/Apo2L may provide the basis for clinical trials of TRAIL-based treatment to improve the outcome of MRT patients. (Pediatr Res 54: 709717, 2003)
Abbreviations
MRT, malignant rhabdoid tumor
TNF, tumor necrosis factor
TRAIL/Apo2L, tumor necrosis factor-related
apoptosis-inducing ligand or Apo2 ligand
$\mathbf{N F}-\boldsymbol{\kappa} \mathbf{B}$, nuclear factor- $\kappa \mathrm{B}$
PI3-kinase, phosphatidylinositol 3-kinase
PI, propidium iodide
MTT, 3-(4,5-dimethylthiazol-2-yl)-2,5-diphenyltetrazolium bromide

MRTs were first described in the kidney as a rare variant of Wilms' tumor with a rhabdomyosarcomatoid pattern. Unfortunately, there is no effective treatment for this disease because it is largely resistant to both chemotherapy and radiotherapy. MRT also has an extremely poor prognosis because of its high potential for metastasis (1). Primary MRT has been described in the CNS, pelvis, and paravertebral regions (2-7). A characteristic feature of MRT cells is the presence of a large eosinophilic inclusion in the cytoplasm $(8,9)$. In the brain, the tumors may present as a mixture of rhabdoid tumor with primitive neuroectodermal tumors, mesenchymal, or epithelial element, an entity referred to as atypical teratoid/rhabdoid tumors $(10,11)$. Most atypical teratoid/rhabdoid tumors dem-

Received October 22, 2002; accepted May 8, 2003.

Correspondence: Shigeru Ohta, M.D., Department of Pediatrics, Shiga University of Medical Science, Seta, Tsukinowa-cho, Ohtsu, Shiga 520-2192, Japan; e-mail: ohta@belle.shiga-med.ac.jp

Supported in part by the Grant of Ministry of Education, Culture, Sports, Science and Technology, Japanese Government Grant-in-aid(C) No.14570741 and (A) No. 14207071.

DOI: 10.1203/01.PDR.0000085038.53151.D0 onstrate monosomy 22 or deletions of chromosome band $22 \mathrm{q} 11$ with alterations of the $h S N F 5 / I N I 1$ gene (12). Recently study revealed that MRT has truncated mutations and homozygous deletions of $h S N F 5 / I N I 1$ gene, suggesting a tumor suppressor gene (13).

TNF-related apoptosis-inducing ligand or Apo2 ligand (TRAIL/Apo2L) was recently identified as a member of the TNF superfamily of cell death-inducing ligands. This ligand is a type II transmembrane protein that triggers apoptosis mainly in tumor cells $(14,15)$. TRAIL induces apoptotic cell death in many cancer or transformed cells both in vitro and in various in vivo tumor models (16-20). However, its proapoptotic effects are minimal in normal human cells in vitro and in TRAIL-treated animals (14, 21-25). TRAIL mRNA is constitutively present in many tissues, unlike the restricted expression of other proapoptotic members of the TNF family $(21,22)$. This feature of TRAIL/Apo2L prompted us to investigate whether this cell death ligand is active against MRT cells.

TRAIL/Apo2L has four different specific receptors: two proapoptotic death receptors (DR4, DR5), and two antiapop- 
totic decoy receptors (DcR1, DcR2). Normal cells express all these receptors. The preferential expression of these decoy receptors in normal tissues led to the hypothesis that both molecules protect normal tissues from TRAIL-induced apoptosis by competing with the DR4 and DR5 receptors for limited amounts of ligand $(22,26-28)$. The increased TRAIL sensitivity of tumor cells has been postulated to result from the lack of DcR1 or DcR2 expression, and recently study revealed that DcR1 and DcR2 expressions were down-regulated in neuroblastoma and primitive neuroectodermal tumor cell lines (29).

Doxorubicin had been reported to enhance the apoptotic activity of TRAIL and to up-regulate DR5 receptor expression in MCF-7 breast cancer cell line (30) and multiple myeloma cells (31).

$\mathrm{NF}-\kappa \mathrm{B}$ is an important part of cell survival pathways and confers protection of tumor cells against various proapoptotic agents $($ i.e. $\mathrm{TNF} \alpha)(32,33)$. The cell-permeable peptide SN50 binds to the nuclear localization sequence of NF- $\kappa \mathrm{B}$, blocks its nuclear translocation, and inhibits its transcriptional activity (34).

On cancer cell proliferation, the PI3-kinase/Akt pathway is also important. Akt is activated in response to activation by many different growth factors (i.e. platelet-derived growth factor) (35), and inhibits apoptotic cell death in cancer cells. Once activated, Akt exerts antiapoptotic effects through phosphorylation of substrates such as Bad (36) and caspase-9 (37), and activates the antiapoptotic NF- $\kappa \mathrm{B}$-mediated transcriptional pathway $(38,39)$.

The aim of this study was to examine whether TRAIL/ Apo2L can induce apoptosis in human MRT cell lines and to investigate the difference between TRAIL receptor expressions in TRAIL-sensitive versus TRAIL-resistant MRT cells. Moreover, we wished to examine whether doxorubicin, NF- $\kappa \mathrm{B}$ inhibitor (SN50), and PI3-kinase/Akt inhibitor (wortmannin, LY294002) can enhance the activity of TRAIL/Apo2L ligands in these cells. Our results suggest the possibility for use of TRAIL/Apo2L as a novel therapeutic agent for MRT treatment.

\section{METHODS}

\section{Cell Culture}

The MRT cell lines used in this study (TM87-16, STM9101, TTC642, TTC549, and TTC1240) were provided by Dr. Hiroyuki Shimada and Dr. Timothy J. Triche (Childrens Hospital Los Angeles, Los Angeles, CA, U.S.A.). The MRT cell line YAM-RTK1 was provided by Dr. Kanji Sugita (Yamanashi Medical University, Kofu, Japan). To investigate these cells in our study, informed consent was obtained from those laboratories. Diagnosis of these MRT cell lines was based on finding the presence of a large eosinophilic inclusion in the cytoplasm by light microscopy, and it was recently reported that these cell lines have homozygous deletion (TM87-16, TTC 549, STM91-01, YAM-RTK1) and point mutations (TTC642, TTC1240) of the hSNF5/INI1 gene (40). Ewing's sarcoma cell line ES-1OT was established from primary tumors in our laboratory. HeLa cells were used as a positive control for DR4/DR5 expression. The MRT and Ewing's sarcoma cell lines used in this study were isolated from the 16th through 23rd passages. The cells were cultured in RPMI 1640 (GIBCO, Gaithersburg, MD, U.S.A.) supplemented with $2.5 \%$ to $5 \%$ FCS (ICN Biomedicals Inc, Cleveland, OH, U.S.A.).

\section{Reagents}

Antibodies against DR4, DR5, DcR1, and $\beta$-actin were purchased from Santa Cruz Biotechnology Inc (Santa Cruz, CA, U.S.A.). Anti-DcR2 and human-recombinant TRAIL, the inhibitory peptide SN50, an inactive control for SN50 peptide (SN50M), wortmannin, and LY294002 were from Calbiochem (San Diego, CA, U.S.A.). Doxorubicin was from Sigma Chemical Co (St. Louis, MO, U.S.A.). Enhanced chemiluminescence Western blot detection reagents, which include the peroxidaselabeled anti-mouse and anti-rabbit secondary antibodies, were from Amersham Pharmacia Biotech Inc (Arlington Heights, IL, U.S.A.); goat anti-rabbit IgG (FITC)-conjugated F(ab')2 fragment (Organon Teknika Corp, West Chester, PA, U.S.A.), rat anti-mouse $\operatorname{IgG}$ (FITC)-conjugated $\mathrm{F}\left(\mathrm{ab}^{\prime}\right) 2$ fragment, and rat anti-goat IgG (FITC)-conjugated $\mathrm{F}\left(\mathrm{ab}^{\prime}\right) 2$ fragment (Vector Laboratories, Inc, Burlingame, CA, U.S.A.) were used for immunofluorescence examination. Coomassie protein assay reagent kit was from Pierce, Inc (Rockford, IL, U.S.A.). The annexin V-PI early apoptosis detection kit was from Medical \& Biologic Laboratories Co, LTD (Nagoya, Japan). PCR kits for DNA ladder assays were obtained from Maxim Biotech, Inc (San Francisco, CA, U.S.A.), and MTT was obtained from Nachalai tesque (Kyoto, Japan).

\section{Western Blot Analysis}

Six MRT cell lines and one Ewing's sarcoma cell line were examined by Western blot analysis for the expression of the DR4, DR5, DcR1, and DcR2 TRAIL/Apo2L receptors. For the doxorubicin experiments, MRT cells were preincubated with doxorubicin $(250$ or $500 \mathrm{ng} / \mathrm{mL}$ ) for $24 \mathrm{~h}$. Protein concentrations were measured using Coomassie protein assay reagent kit (Pierce, Inc). The protein samples were subjected to $7.5 \%$ SDS-PAGE and transferred onto polyvinylidine difloride (PDVF) membranes (Bio-Rad Laboratories, Inc., Hercules, CA). The membranes were blocked with $3 \%$ nonfat milk in Tris-buffered saline (TBS) containing 0.1\% Tween 20 and incubated with an anti-DR4, -DR5, -DcR1, or -DcR2 antibody and then with horseradish-peroxidase-conjugated secondary antibodies. The immunoblots were visualized using enhanced chemiluminescence detection (enhanced chemiluminescence plus detection reagent; Amersham Pharmacia Biotech).

\section{Detection of TRAIL Receptor by Flow Cytometric Analysis}

The MRT cell lines were characterized for their surface receptor expression by flow cytometry. HeLa cells served as a positive control for DR4/DR5 expression and as a negative control for DcR1 and DcR2 expression. MRT cells $\left(1 \times 10^{6}\right)$ were preincubated with doxorubicin $(250$ or $500 \mathrm{ng} / \mathrm{mL}$ ) for $24 \mathrm{~h}$ and incubated with each anti-TRAIL receptor antibody or a respective control for $1 \mathrm{~h}$. DcR1 and DR5 expressions were 
assessed with anti-DcR1 and anti-DR5 MAb and confirmed with goat anti-human DcR1 and DR5 polyclonal antibodies. DR4 expression was assessed with anti-DR4 MAb and mouse anti-DR4 MAb. DcR2 expression was assessed with anti-DcR2 $\mathrm{MAb}$ and a rabbit anti-DcR2 polyclonal antibody. Cells were washed with PBS and incubated for $1 \mathrm{~h}$ with rat anti-goat $\operatorname{IgG}$ FITC-conjugated $\mathrm{F}\left(\mathrm{ab} \mathrm{b}^{\prime}\right) 2$ fragment for anti-DcR1 and anti-DR5 $\mathrm{MAb}$ expression, with a rat anti-mouse IgG FITC-conjugated $\mathrm{F}(\mathrm{ab}$ ')2 fragment for DR4 MAb expression, or with an antirabbit IgG FITC-conjugated $\mathrm{F}\left(\mathrm{ab}^{\prime}\right) 2$ fragment for DcR2 MAb expression. Cells were washed with PBS and analyzed by flow cytometry with a fluorescence-activated cell sorting scan using CELLQuest software (Becton-Dickinson, Mountain View, CA, U.S.A.).

\section{Survival, Death, and Apoptosis Assays}

MTT colorimetric assay. MRT or Ewing's sarcoma cells (2 $\times 10^{4}$ ) were plated in a 96-well microplate and incubated for $18 \mathrm{~h}$ with TRAIL $(10-1000 \mathrm{ng} / \mathrm{mL})$ in $2.5-5 \%$ bovine serumsupplemented RPMI medium. In some experiments, MRT cells were pretreated with doxorubicin $(250$ or $500 \mathrm{ng} / \mathrm{mL}$ for $4 \mathrm{~h}$ ), the NF- $\kappa$ B inhibitory peptide (SN50, SN50M) at $30 \mathrm{ng} / \mathrm{mL}$ for $3 \mathrm{~h}$, or PI3-kinase/Akt pathway inhibitor (200 nM wortmannin, $20 \mu \mathrm{M}$ LY294002 for $4 \mathrm{~h}$ ) before exposure to TRAIL. At the end of treatment, cells were incubated with $1 \mathrm{mg} / \mathrm{mL}$ MTT for $4 \mathrm{~h}$ at $37^{\circ} \mathrm{C}$. A mixture of isopropanol and $1 \mathrm{~N} \mathrm{HCl}(24: 1$, $\mathrm{vol} / \mathrm{vol}$ ) was added with pipetting to dissolve the formazan crystals. Dye absorbance in viable cells was measured at 595 $\mathrm{nm}$, with $670 \mathrm{~nm}$ used as a reference wavelength.

Annexin V/PI staining. Detection of early apoptotic cells was performed with an MEBOCYTO apoptosis kit (Annexin V-FITC kit, Medical \& Biologic Laboratories Co, LTD). Cells $\left(2 \times 10^{5}\right)$ were exposed for $4 \mathrm{~h}$ to TRAIL or media, washed with PBS, resuspended in binding buffer, incubated in the dark at room temperature with annexin V-FITC and PI for $15 \mathrm{~min}$, and analyzed by dual-color flow cytometry. Cells that were annexin V-FITC ${ }^{+}$, with translocation of phosphatidylserine from the inner to the outer leaflet of the plasma membrane, and $\mathrm{PI}^{-}$, with intact cellular membranes, were considered to be early apoptotic cells.

DNA ladder assay. For the detection of nucleosomal ladders in apoptotic cells, a DNA Ladder Assay PCR kit (Maxim Biotech, Inc) was used. Cells $\left(1 \times 10^{6}\right)$ were incubated with $10-1000 \mathrm{ng} / \mathrm{mL}$ TRAIL for $24 \mathrm{~h}$, and genomic DNA was then extracted from the cells by Maxim's DNA isolation kit (Maxim Biotech, Inc). Adaptor-ligation of DNA was performed at $16^{\circ} \mathrm{C}$ for $16 \mathrm{~h}$, and PCR was then initiated using the adaptor-primer. Aliquots of PCR products were electrophoresed through $2 \%$ agarose gels containing $0.2 \mathrm{mg} / \mathrm{mL}$ ethidium bromide.

\section{RESULTS}

TRAIL/Apo2L-induced apoptosis in MRT cell lines. In three of the six MRT cell lines tested (TM87-16, TTC642, and STM91-01) and in the ES-1OT cell line, TRAIL/Apo2L induced significant reduction of cell survival as assessed by the MTT colorimetric assay (Fig. 1A). The survival rate of STM91-01 and ES-1OT cells was more than 70\% after treat-
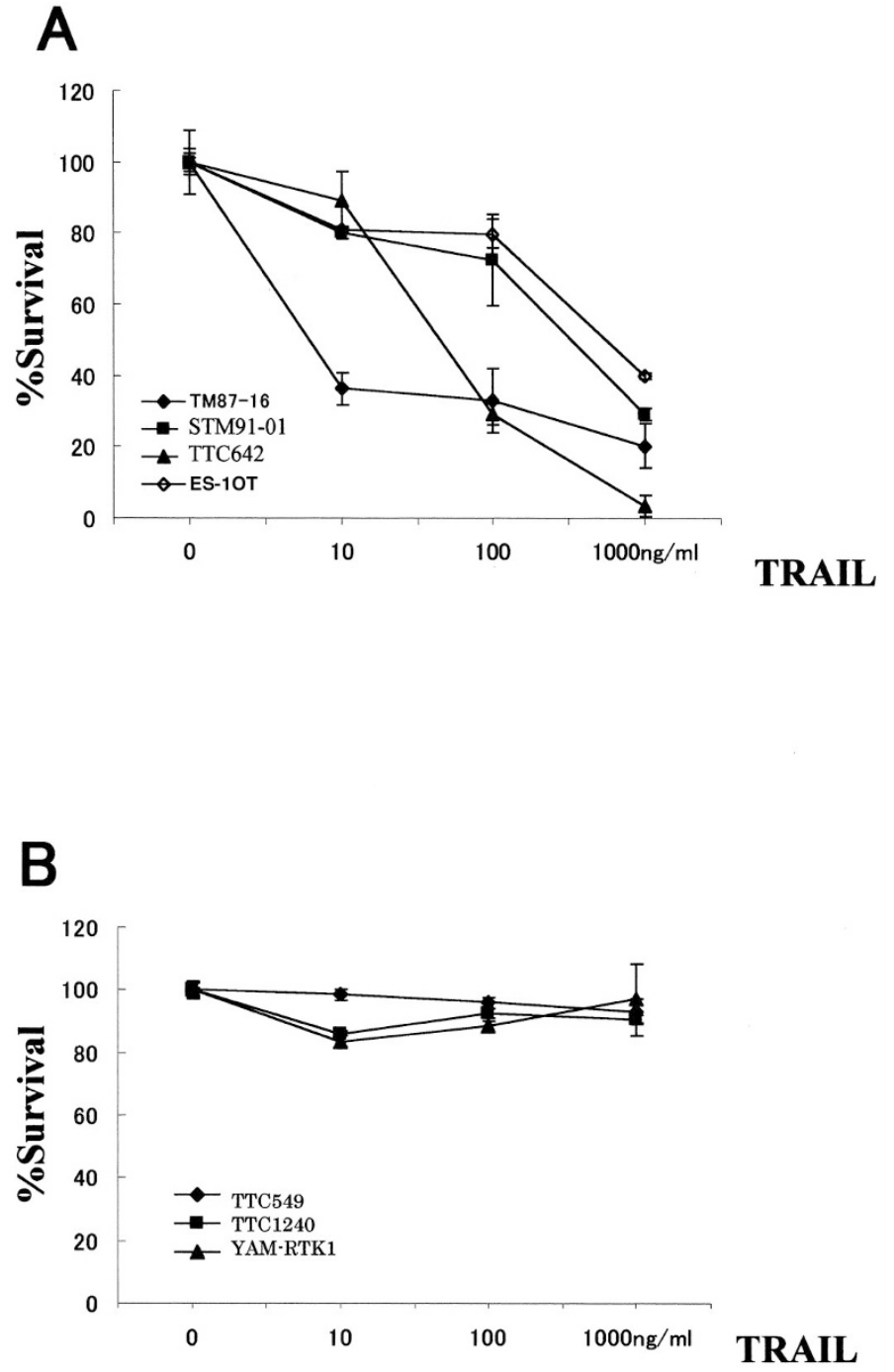

Figure 1. MTT colorimetric assay of MRT cells cultured with human recombinant TRAIL. Dose-response survival curves were generated for MRT cells treated with TRAIL $(10-1000 \mathrm{ng} / \mathrm{mL})$ for $18 \mathrm{~h}$. $A$, survival curves for TRAIL-sensitive MRT cell lines: TM87-16, TTC642, STM91-01, and ES1OT. B, survival curves for TRAIL-resistant MRT cell lines: TTC549, TTC1240, and YAM-RTK1.

ment with $100 \mathrm{ng} / \mathrm{mL}$ of TRAIL. In contrast, TM87-16 and TTC642 cells showed less than $40 \%$ survival at the same dose, so these lines were considered TRAIL-sensitive. Three cell lines (TTC549, TTC1240, and YAM-RTK1) showed more than $80 \%$ survival even after exposure to a high dose $(1000$ $\mathrm{ng} / \mathrm{mL}$ ) of TRAIL/Apo2L. So these were considered to be TRAIL-resistant (Fig. 1B).

Apoptosis in TRAIL-sensitive or -resistant MRT cells was confirmed by annexin V-FITC/PI staining: early apoptotic cell death was identified with annexin $\mathrm{V}^{+} \mathrm{PI}^{-}$staining, and late apoptotic cell death and necrosis were identified with annexin $\mathrm{V}^{+} \mathrm{PI}^{+}$staining. In contrast with TRAIL-untreated cells (Fig. $2 A$ ), TRAIL-induced apoptotic cell death occurred after $4 \mathrm{~h}$ (Fig. 2B).

We also examined whether TRAIL-induced, dose-dependent apoptotic cell death occurs in MRT cell lines by PCR-DNA ladder assay. TM87-16 cells were incubated with increasing 


\section{A TTC642 control}

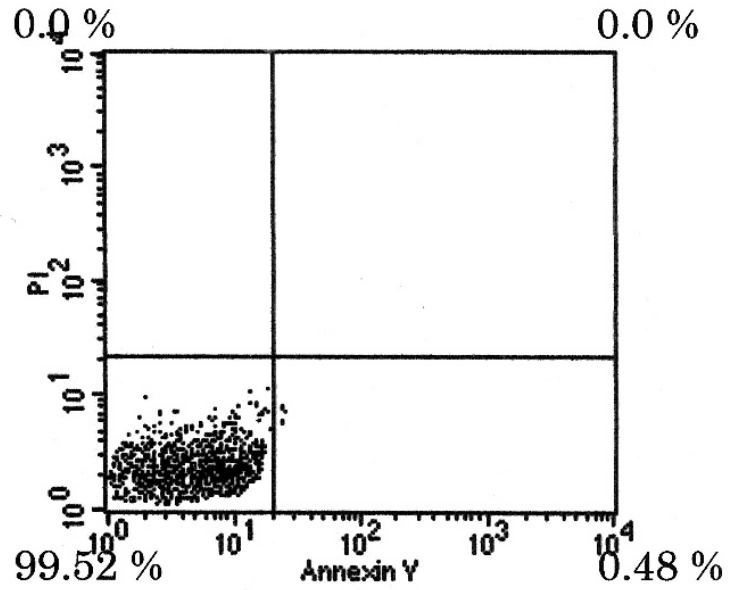

\section{B TTC642 TRAIL $250 \mathrm{ng} / \mathrm{ml}$}

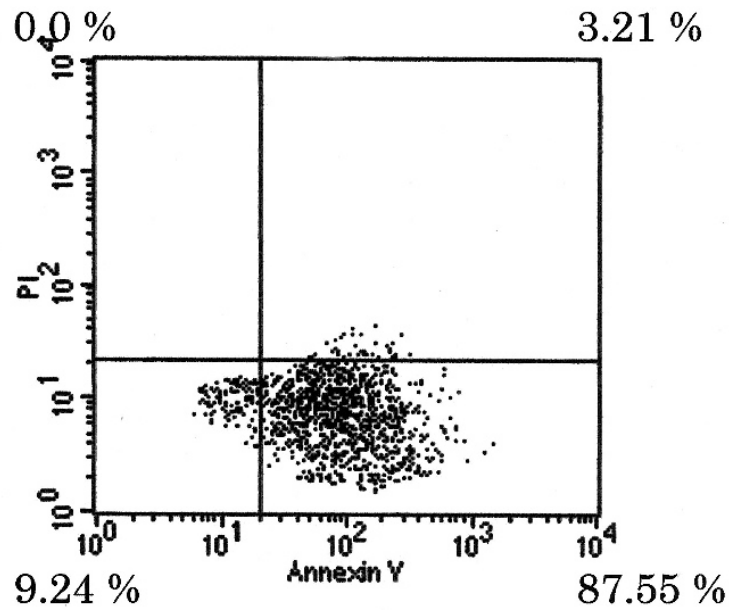

Figure 2. Annexin V/PI staining of MRT cells cultured with human recombinant TRAIL. MRT cells were cultured for $4 \mathrm{~h}$ with TRAIL $(250 \mathrm{ng} / \mathrm{mL})$. A, TRAIL-untreated cells. $B$, significant induction of apoptotic cell death (annexin $\mathrm{V}^{+} \mathrm{PI}^{-}$status) detected in the TTC642 cell line.

concentrations $(0,10,50,100$, and $1000 \mathrm{ng} / \mathrm{mL})$ of TRAIL/ Apo2L for $4 \mathrm{~h}$. As the concentration of TRAIL/Apo2L increased, the production of DNA ladder fragments was also increased (Fig. 3). However, TRAIL-resistant cell lines did not have increased DNA ladder fragments after treatment with TRAIL (data not shown).

TRAIL receptor expression in MRT cell lines. We investigated how TRAIL/Apo2L sensitivity of MRT cells correlates with the expression of TRAIL receptors using immunoblotting method. Western blot analysis of six MRT cell lines (TM8716, TTC642, TTC549, STM91-01, YAM-RTK1, and TTC1240) revealed expression of all four receptors (DR4, DR5, DcR1, and DcR2). In all MRT cell lines, the levels of

\section{$\begin{array}{llllll}1 & 2 & 3 & 4 & 5 & \mathrm{M}\end{array}$}

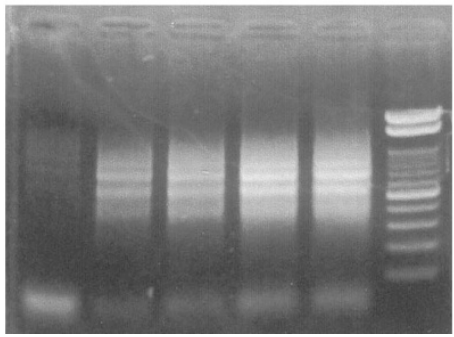

1. control

2. TRAIL $10 \mathrm{ng} / \mathrm{ml}$

3. TRAIL $50 \mathrm{ng} / \mathrm{ml}$

4. TRAIL $100 \mathrm{ng} / \mathrm{ml}$

5. TRAIL $1000 \mathrm{ng} / \mathrm{ml}$

M. marker

Figure 3. Detection of apoptotic DNA in the TM87-16 cell line cultured with TRAIL. TM87-16 MRT cells were cultured for $4 \mathrm{~h}$ with TRAIL $(0-1000$ $\mathrm{ng} / \mathrm{mL}$ ). Lane 1, control, cells cultured with $0 \mathrm{ng} / \mathrm{mL}$; lane 2, cultured with 10 $\mathrm{ng} / \mathrm{mL}$ TRAIL; lane 3, cultured with $50 \mathrm{ng} / \mathrm{mL}$ TRAIL; lane 4, cultured with $100 \mathrm{ng} / \mathrm{mL}$ TRAIL; and lane 5, cultured with $1000 \mathrm{ng} / \mathrm{mL}$ TRAIL.

DR4 and DR5 expression were consistently detectable, whereas the expression of DcR1 and DcR2 was variable. In contrast with TRAIL-resistant cells, the expression of DcR2 was low in TRAIL-sensitive cell lines (TM87-16, TTC642, and STM91-01). DcR1 expression levels were not different in TRAIL-sensitive versus TRAIL-resistant MRT cells (Fig. 4).

Doxorubicin induces a significant up-regulation of TRAIL receptors. Next, we examined whether the genotoxic agent doxorubicin can cause an increase in the expression levels of TRAIL receptors in MRT cell lines. TM87-16 MRT cell line was treated with doxorubicin ( 250 or $500 \mathrm{ng} / \mathrm{mL}$ ) for $24 \mathrm{~h}$, and TRAIL receptor expression was analyzed using Western blot and flow cytometric analyses. After treatment with doxorubicin, DR4 and DcR2 expression was somewhat up-regulated, whereas DR5 was significantly up-regulated (Fig. $5 A$ ). On the contrary, after treatment with doxorubicin, flow cytometric analysis revealed that surface expression of DcR1 was not up-regulated, whereas expression of DR5 increased (Fig. 5B). The same results were observed in the other five MRT cell lines (data not shown).

Doxorubicin enhances induction of apoptotic cell death by TRAIL receptors in MRT cell lines. We investigated whether doxorubicin could enhance the proapoptotic effect of TRAIL in

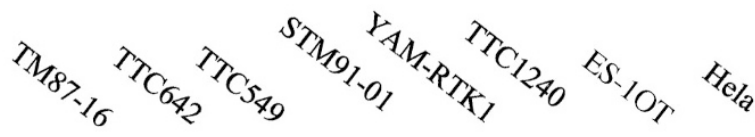

DR4

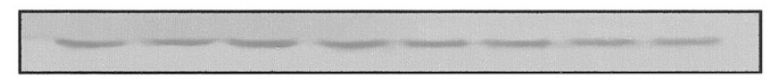

DR5

DcR1
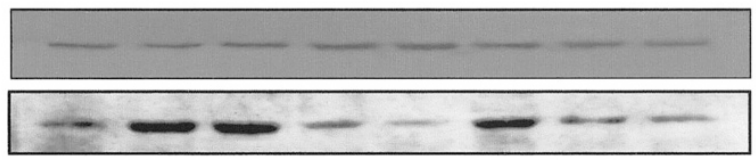

DcR2

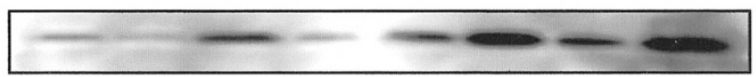

Actin

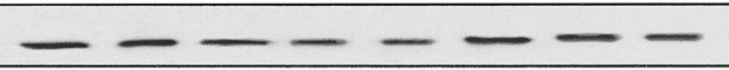

Figure 4. Detection of TRAIL receptor expression by Western blot analysis. Western blot analysis for DR4, DR5, DcR1, and DcR2 receptors was performed in MRT cells. ES-1OT (Ewing's sarcoma cell line) and HeLa cell were used as a positive control. 
A

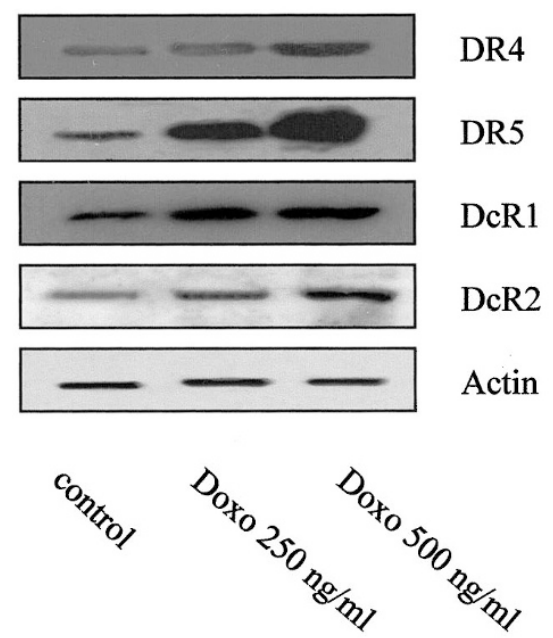

B

DR4
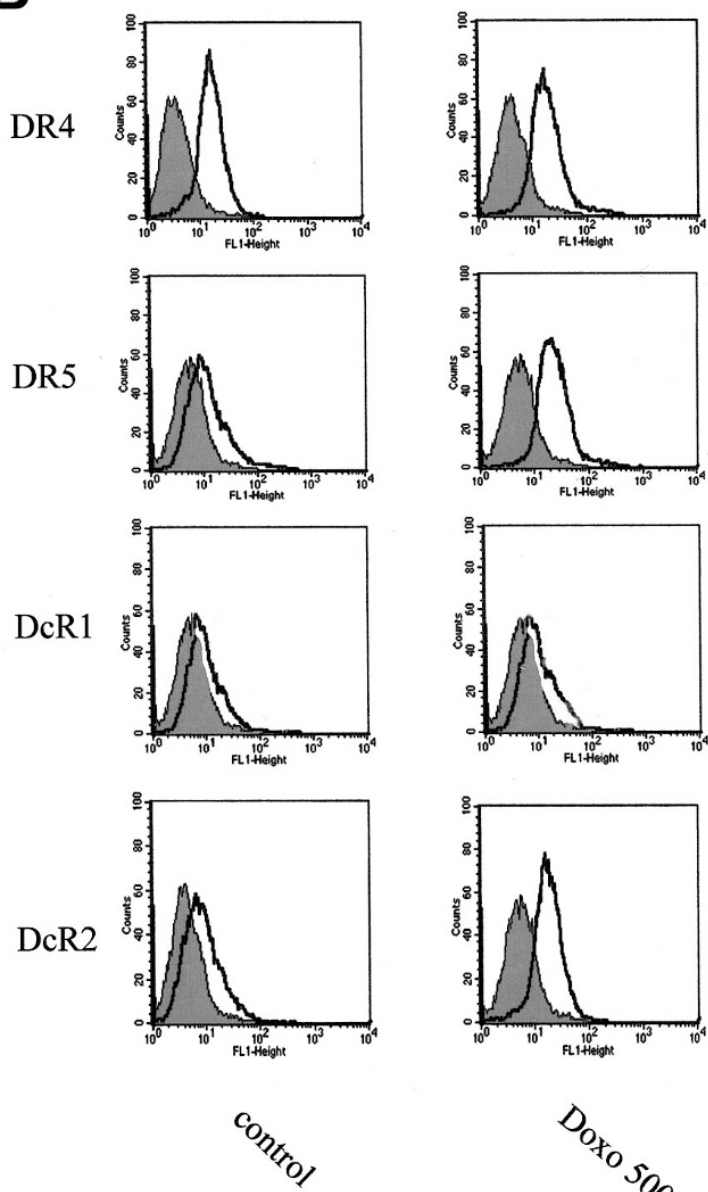
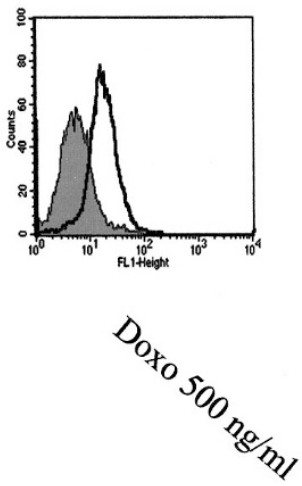

Figure 5. Doxorubicin (Doxo) up-regulates DR5 receptor expression in the TM87-16 cell line. $A$, immunoblotting analysis indicates significant dose-dependent up-regulation of DR5 expression by doxorubicin treatment $(250$ or $500 \mathrm{ng} / \mathrm{mL})$. Doxorubicin also induces up-regulation of DR4 expression. $B$, flow cytometric analysis shows significant up-regulation of surface DR5 expression by doxorubicin treatment $(500 \mathrm{ng} / \mathrm{mL})$. However, surface expression of DcR1 is not overexpressed by pretreatment with doxorubicin.

TRAIL-sensitive MRT cell lines. TM87-16 and TTC642 cell lines, TRAIL-sensitive MRT cells, were pretreated with doxorubicin $(250$ or $500 \mathrm{ng} / \mathrm{mL})$ for $4 \mathrm{~h}$ and then incubated with TRAIL/Apo2L (100 ng/mL) for $18 \mathrm{~h}$. MTT colorimetric assay revealed that doxorubicin significantly enhanced the proapoptotic effect of TRAIL/Apo2L in these cell lines, reducing their survival rate to levels lower than those expected. Moreover, doxorubicin enhanced the susceptibility to TRAIL in YAMRTK1, TRAIL-resistant MRT cell. Doxorubicin and TRAIL/ Apo2L therefore appear to have a synergistic interaction in promoting apoptosis (Fig. 6).

$\mathrm{NF- \kappa B}$ inhibition or PI3-kinase inhibition modulates the effect of TRAIL on MRT cells. We examined whether inhibition of NF- $\kappa \mathrm{B}$ transcriptional activity could modulate the response of MRT cells to TRAIL. TTC642, TRAIL-sensitive MRT cell, STM91-01, moderately TRAIL-sensitive cell, and YAM-RTK1 and TTC549, TRAIL-resistant cells, were preincubated for $4 \mathrm{~h}$ with the cell-permeable peptide SN50 at 30 $\mathrm{ng} / \mathrm{mL}$, a nontoxic concentration (31), and then incubated with TRAIL/Apo2L (50 ng/mL) for $18 \mathrm{~h}$. Pretreatment with SN50 enhanced the sensitivity of each MRT cell line to TRAIL (Fig.
7), whereas an inactive control for SN50 peptide, SN50M, did not reduce the survival rate in spite of TRAIL (data not shown).

We also investigated whether PI3-kinase/Akt inhibitor sensitized MRT cells to TRAIL-induced apoptosis. TTC642 and YAM-RTK1 were pretreated with wortmannin $(200 \mathrm{nM})$ or LY294002 $(20 \mu \mathrm{M})$ for $4 \mathrm{~h}$ and then TRAIL $(50 \mathrm{ng} / \mathrm{mL})$ was added for $18 \mathrm{~h}$. Wortmannin/LY294002 pretreatment significantly augmented the sensitivity of TRAIL-sensitive MRT cells to TRAIL, and the pretreatment of PI3-kinase inhibitor also enhanced the sensitivity of TRAIL-resistant MRT cells (Fig. 8).

\section{DISCUSSION}

MRTs are basically resistant to current chemotherapeutic agents, radiotherapy, and stem cell transplantation, and therefore have an extremely poor prognosis. Members of the TNF family (TNF, Fas ligand, and TRAIL) have been shown to be potent inducers of apoptotic cell death in various cancer cell lines. TNF and Fas ligand are toxic to both cancer tissue and 

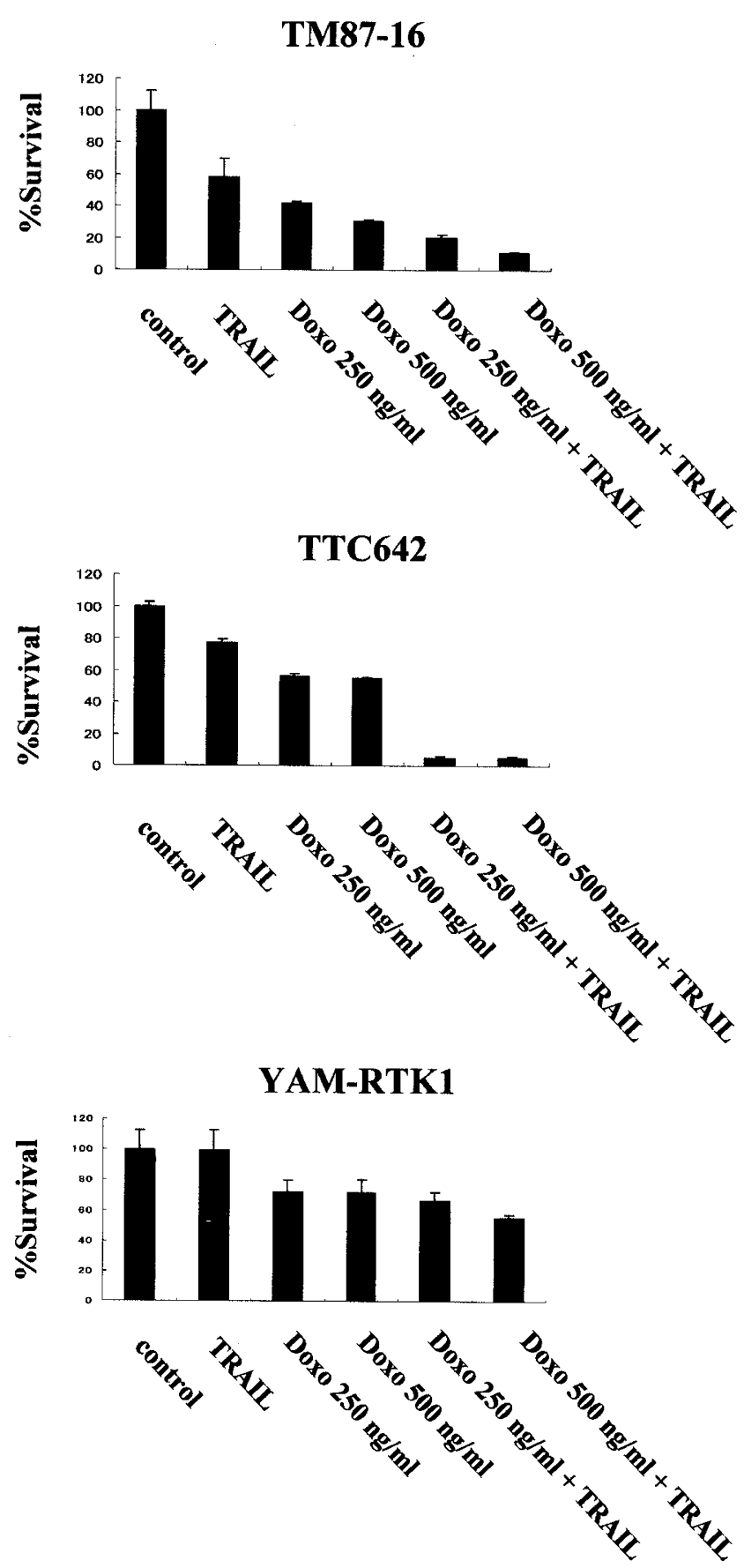

Figure 6. Doxorubicin (Doxo) enhances the sensitivity to TRAIL in TM8716, TTC 642, and YAM-RTK1 cell lines. MTT colorimetric assay of TM87-16 and TTC642 (TRAIL-sensitive) cells and YAM-RTK1 (TRAIL-resistant) cells cultured with doxorubicin $(250,500 \mathrm{ng} / \mathrm{mL})$ or human recombinant TRAIL $(100 \mathrm{ng} / \mathrm{mL})$. Doxorubicin and TRAIL together significantly reduce the survival rate of TM87-16 and TTC642 cells. Pretreatment of doxorubicin enhances the susceptibility to TRAIL in YAM-RTK1.

normal tissue, whereas TRAIL exerts potent antitumor activity in vitro without exhibiting systemic toxicity. It has been reported that TRAIL can induce apoptosis in some neoplasias (41-44), and a recent study revealed that TRAIL is hepatotoxic in cholestasis in vivo (45). This prompted us to examine whether TRAIL/Apo2L can induce apoptosis in MRT cells. In this study, we found that apoptosis can be induced by TRAIL/
Apo2L in some MRT cell lines, and our results demonstrate that MRT cell lines can either be TRAIL/Apo2L-sensitive or TRAIL/Apo2L-resistant.

The Western blot analysis of TRAIL receptor expression in MRT cell lines was designed to identify what confers TRAIL sensitivity to MRT cells. Decoy receptors do bind ligand; they inhibit the effects of ligand binding or effective signaling. Although the death signal of DR4 and DR5 receptor is expressed in all MRT cell lines, Western blot analysis revealed that DR5 expression was variable in all of the cell lines. The expression levels of DR4 and DR5 did not correlate with TRAIL sensitivity or resistance in MRT cell lines, which is consistent with some previous observations in various tumors $(30,46,47)$ but not with others (48). A previous study has reported that glioma cells have an increased level of expression for the DR5 death receptor (44). It has also been described that other neoplasias have mutations in the DR5 receptor death domain $(49,50)$. It is possible that our TRAIL-resistant MRT cell lines might also have mutations in this domain.

It has been suggested that DcR1 and DcR2 expression may provide a mechanism for cells to avoid TRAIL/Apo2L-induced apoptosis; therefore, we investigated whether expression of these decoy receptors correlate with TRAIL resistance. We found that DcR1 and DcR2 are expressed in all MRT cell lines, particularly in the TRAIL-resistant cell lines TTC549 and TTC1240. We also found that the expression level of DcR2 was low in TRAIL-sensitive MRT cell lines. The same results were reported recently (29), and some reports suggested that the expression levels of decoy receptor were not related to TRAIL sensitivity in various cancer cells $(25,31,51,52)$. Our findings suggest that there is correlation between TRAIL decoy receptor expression and susceptibility to TRAIL-induced apoptosis in MRT cell lines.

Our results could be explained by the presence of cell death inhibitors in MRT cells. FLIP [FLICE (Fas-associated death domain-like IL-1 $\beta$-converting enzyme) -inhibitory protein], a caspase inhibitor, may play a role in TRAIL-induced apoptotic cell death: some investigators have reported that FLIP could be a predictor of TRAIL sensitivity (53), although others have not been able to show such a correlation (48). Other investigators recently reported that in neuroblastoma cell lines, resistance to TRAIL-induced apoptotic cell death correlated with the loss of caspase-8 expression (54). Downstream intracellular modulators of apoptosis may therefore regulate susceptibility to TRAIL/Apo2L-induced apoptosis in MRT cells. However, the mechanism underlying the resistance in TRAIL-induced apoptotic cell death remains to be elucidated.

Because doxorubicin has been reported to up-regulate expression of the DR5 death signaling receptor (54-56), we investigated whether it could sensitize MRT cells to TRAIL/ Apo2L. We found that in MRT cell lines, doxorubicin somewhat induces the up-regulation of DR4 and DcR2 expression and significantly induces up-regulation of DR5 expression, as shown by Western blot and flow cytometric analyses. Previous reports have described similar findings in other malignancies (55-57). We have also demonstrated that pretreatment with doxorubicin at clinically relevant concentrations (31) significantly enhances the TRAIL sensitivity of MRT cells. Further- 
TTC642

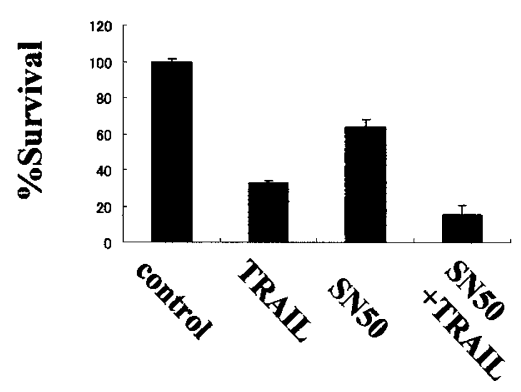

STM91-01

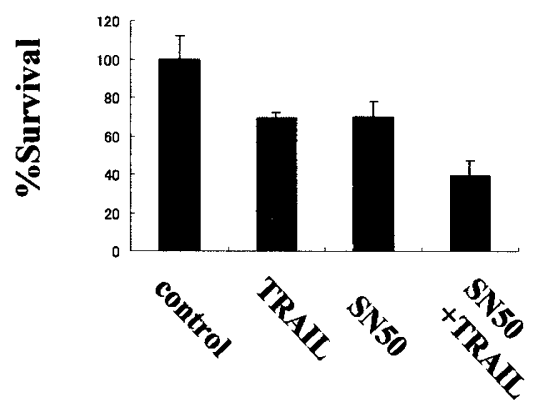

YAM-RTK1

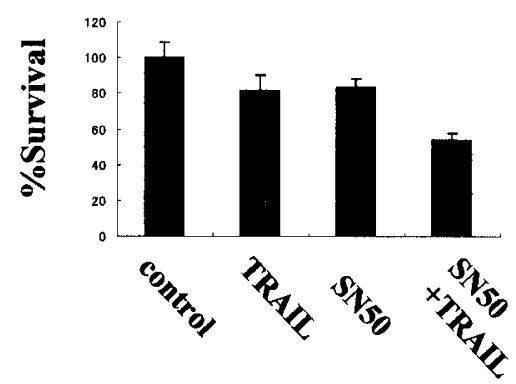

TTC549

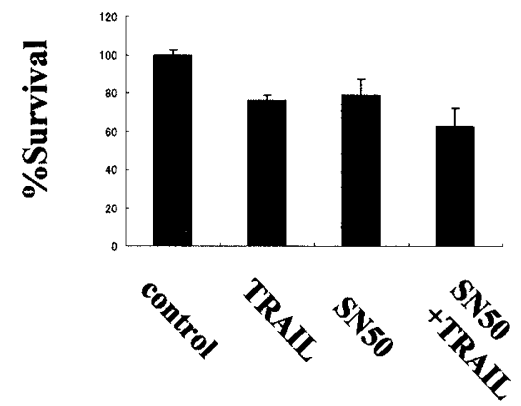

Figure 7. NF- $\kappa$ B inhibitor SN50 with TRAIL pretreatment increased the number of apoptotic cell deaths in TTC642, STM91-01, YAM-RTK1, and TTC549 cell lines. MTT assay of TTC642 and STM91-01 (TRAIL-sensitive) MRT cells and YAM-RTK1 and TTC549 (TRAIL-resistant) MRT cells cultured with NF- $\kappa$ B (30 ng/mL, nontoxic dose) or human recombinant TRAIL $(100 \mathrm{ng} / \mathrm{mL})$. NF- $\kappa$ B inhibitor and TRAIL together reduce the survival rate of TRAIL-sensitive and -resistant MRT cells.
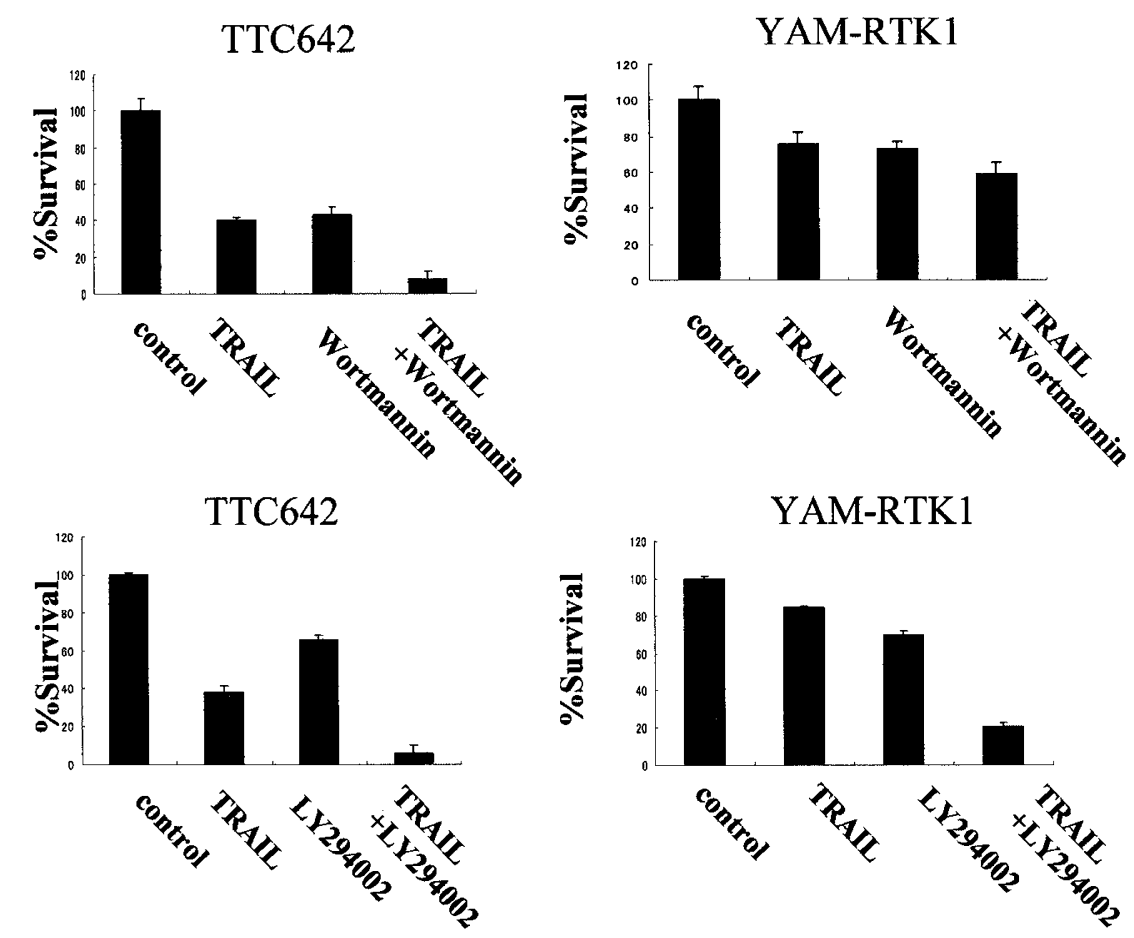

Figure 8. PI3-kinase inhibitor enhanced the susceptibility to TRAIL in MRT cell lines. MTT assay of MRT cells cultured with PI3-kinase inhibitor (200 nM wortmannin and $20 \mu \mathrm{M} \mathrm{LY294002)}$ or human recombinant TRAIL $(50 \mathrm{ng} / \mathrm{mL})$. Wortmannin/LY294002 and TRAIL together significantly increased the apoptotic cell death of TTC642. STM91-01 cells exhibited the same result (data not shown). Pretreatment with wortmannin/LY294002 also reduced the survival rate of the TRAIL-resistant YAM-RTK1 cell line.

more, doxorubicin enhanced the susceptibility to TRAIL in TRAIL-resistant MRT cells. Doxorubicin and TRAIL may synergistically induce apoptotic cell death via the up-regulation of TRAIL receptor expression.
TRAIL/Apo2L binding to DR4 and DR5, as well as to decoy receptor DcR2, activates NF- $\kappa$ B by receptor-interacting protein (RIP)-mediated activation of I $\mathrm{BB}$ kinase $(58-60)$. Previous reports informed that the constitutive activation of NF- $\kappa \mathrm{B}$ 
prevented TRAIL-induced apoptosis and inhibition of NF- $\kappa \mathrm{B}$ activity enhanced the susceptibility to TRAIL in renal carcinoma cells or breast cancer cells $(61,62)$. However, NF- $\kappa$ B activity in MRT cells still remains unknown. Therefore, we investigated whether SN50, which inhibits NF- $\kappa$ B, could also sensitize MRT cells to TRAIL/Apo2L. Pretreatment with SN50 enhanced the sensitivity to TRAIL in TRAIL-sensitive cell lines, whereas SN50 reversed the TRAIL resistance of TTC549, YAM-RTK1, and TTC1240 MRT cells. These data demonstrate that modulation of NF- $\kappa \mathrm{B}$ activation is a key determinant of the sensitivity of MRT cells to TRAIL-induced apoptosis.

PI3-kinase/Akt also plays an important role in cell survival pathways. Recent studies have shown that constitutively active Akt in tumor cells can inhibit the ability of TRAIL-inducing apoptosis (63) and that TRAIL-resistant malignant cells lack active lipid phosphatase PTEN (phosphatase and tension homologue deleted on chromosome 10, a negative regulator of the PI3-kinase/Akt pathway (64). However, the effects of specific inhibition of PI3-kinase/Akt activity in MRT cells still remain unknown. We investigated whether the PI3-kinase/Akt signaling pathway could modulate the sensitivity of MRT cells to TRAIL in MRT cell lines. PI3-K inhibitors (wortmannin, LY294002) enhanced the susceptibility to TRAIL/Apo2L in TRAIL-sensitive MRT cells. And these PI3-K inhibitors with TRAIL reduced the survival rate of TRAIL-resistant MRT cells. Thus, TRAIL in combination with agents that downregulate Akt activity can be used to induce cell death in MRT cells.

\section{CONCLUSIONS}

In summary, although TRAIL/Apo2L is a potent inducer of apoptosis in MRT cells, sensitivity of these cells to TRAIL/ Apo2L is not correlated with the expression levels of DR4 and DR5, whereas the expression of decoy receptors DcR1 and DcR2 may have correlation with the susceptibility to TRAIL. Doxorubicin enhances the expression levels of DR4 and DcR2 and significantly up-regulates the expression levels of DR5. Doxorubicin also enhances the sensitivity of MRT cell lines to TRAIL/Apo2L. Moreover, NF- $\kappa$ B inhibition and PI3-kinase/ Akt signaling inhibition enhanced the sensitivity of these cells to TRAIL. These studies may provide a basis for clinical use of TRAIL/Apo2L for the treatment of MRT, but further testing is required in xenografts or other animal models, before use in humans.

Acknowledgments. The authors thank Dr. Timothy J Triche, Dr. Hiroyuki Shimada (Children's Hospital, Los Angeles, CA), and Dr. Kanji Sugita (Yamanashi Medical University. Kofu). We also thank Masaki Suzaki (Central Research Laboratory, Shiga University of Medical Science).

\section{REFERENCES}

1. Beckwith JB, Palmer NF 1978 Histopathology and prognosis of Wilms' tumor: Results from the first National Wilms' Tumor study. Cancer 41:1937-1948

2. Biggs PJ, Garen PD, Powers JM, Garvin AJ 1987 Malignant rhabdoid tumor of the central nervous system. Hum Pathol 18:332-337
3. Jakate SM, Marsden HB, Ingram L 1988 Primary rhabdoid tumor of brain. Virchows Arch A Pathol Anat Histopathol 412:393-397

4. Blatt J, Russo P, Taylor S 1986 Extrarenal rhabdoid sarcoma. Med Pediatr Oncol $14: 221-226$

5. Frierson HF, Mills SE, Inners DJ 1985 Malignant rhabdoid tumor of the pelvis. Cancer 55:1963-1967

6. Schmidt D, Leuschner I, Harms D, Sprenger E, Schafer HJ 1989 Malignant rhabdoid tumor: a morphological and flow cytometric study. Pathol Res Pract 184:202-210

7. Lynch HT, Shurin SB, Dahms BB, Izant RJ, Lynch J, Danes BS 1983 Paravertebral malignant rhabdoid tumor in infancy: in vitro studies of a familial tumor. Cancer 52:290-296

8. Haas JE, Palmer NF, Weinberg AG, Beckwith JB 1981 Ultrastructure of malignant rhabdoid tumor of the kidney: a distinctive renal tumor of children. Hum Pathol 12:646-657

9. Yoshida S, Narita T, Taga T, Ohta S, Takeuchi Y 2002 Malignant rhabdoid tumor shows incomplete neural characteristics as revealed by expression of SNARE complex. J Neurosci Res 69:642-652

10. Rorke LB, Packer RJ, Biegel JA 1996 Central nervous system atypical teratoid/ rhabdoid tumors of infancy and childhood: definition of an entity. J Neurosurg 85:56-65

11. Packer RJ, Biegel JA, Blaney S, Finlay J, Geyer JR, Heideman R, Hilden J, Janss AJ, Kun L, Vezina G, Rorke LB, Smith M 2002 Atypical teratoid/rhabdoid tumor of the central nervous system: report on workshop. J Pediatr Hematol Oncol 24:337-342

12. Biegel JA, Tan L, Zhang F, Wainwright L, Russo P, Rorke LB 2002 Alterations of the $h S N F 5 / I N I 1$ gene in central nervous system atypical teratoid/rhabdoid tumors and renal and extrarenal rhabdoid tumors. Clin Cancer Res 8:3461-3467

13. Versteege I, Sevenet N, Lange J, Rousseau-Merk MF, Ambros P, Handgretinger R, Aurias A, Delattre O 1998 Truncating mutations of hSNF5/INI1 in aggressive paediatric cancer. Nature 394:203-206

14. Walczak H, Miller RE, Ariail K, Gliniak B, Griffith TS, Kubin M, Chin W, Jones J, Woodward A, Le T, Smith C, Smolak P, Goodwin RG, Rauch CT, Schuh JC, Lynch DH 1999 Tumoricidal activity of tumor necrosis factor-related apoptosis-inducing ligand in vivo. Nat Med 5:157-163

15. Ashkenazi A, Dixit VM 1999 Apoptosis control by death and decoy receptors. Curr Opin Cell Biol 11:225-260

16. Walczak H, Degli-Esposti MA, Johnson RS, Smolak PJ, Waugh JY, Boiani N, Timour MS, Gerhart MJ, Schooley KA, Smith CA, Goodwin RG, Rauch CT 1997 TRAIL-R2: a novel apoptosis-mediating receptor for TRAIL. EMBO J 16:53865397

17. Griffith TS, Chin WA, Jackson GC, Lynch DH, Kubin MZ 1998 Intracellular regulation of TRAIL-induced apoptosis in human melanoma cells. J Immunol $161: 2833-2840$

18. Bodmer JL, Holler N, Reynard S, Vinciguerra P, Schneider P, Juo P, Blenis J, Tschopp J 2000 TRAIL receptor-2 signals apoptosis through FADD and caspase-8. Nat Cell Biol 2:241-243

19. Kim EJ, Suliman A, Lam A, Srivastava RK 2001 Failure of Bcl-2 to block mitochondrial dysfunction during TRAIL-induced apoptosis: tumor necrosis-related apoptosis-inducing ligand. Int J Oncol 18:187-194

20. Suliman A, Lam A, Datta R, Srivastava RK 2001 Intracellular mechanism of TRAIL: apoptosis through mitochondrial-dependent and -independent pathways. Oncogene 20:2122-2133

21. Pitti RM, Marsters SA, Ruppert S, Donahue CJ, Moore A, Ashkenazi A 1996 Induction of apoptosis by Apo-2 ligand, a new member of the tumor necrosis factor cytokine family. J Biol Chem 271:12687-12690

22. Wiley SR, Schooley K, Smolak PJ, Din WS, Huang CP, Nicholl JK, Sutherland GR, Smith TD, Rauch C, Smith CA 1995 Identification and characterization of a new member of the TNF family that induces apoptosis. Immunity 3:673-682

23. French LE, Tschopp J 1999 The TRAIL to selective tumor death. Nat Med 5:146-147

24. Gura T 1997 How TRAIL kills cancer cells, but not normal cells. Science 277:768

25. Rieger J, Naumann U, Glaser T, Ashkenazi A, Weller M 1998 APO2 ligand: a novel lethal weapon against malignant glioma? FEBS Lett 427:124-128

26. Pan G, Ni J, Wei Y-F, Yu G-L, Goodwin R, Dixit V M 1997 An antagonist decoy receptor and a death domain-containing receptor for TRAIL. Science 277:815-818

27. Sheridan JP, Masters SA, Pitti RM, Gurney A, Skubatch M, Baldwin D, Ramakrishnan L, Gray CL, Baker K, Wood WI, Goddard AD, Godowski P, Askenazi A 1997 Control of TRAIL-induced apoptosis by a family of signaling and decoy receptors. Science 277:818-821

28. Pan G, Ni J, Yu G-L, Wei Y-F, Dixit V M 1998 TRUNDD, a new member of the TRAIL receptor family that antagonizes TRAIL signaling. FEBS Lett 424:41-45

29. van Noesel MM, van Bezouw S, Salomons GS, Voute PA, Pieters R, Baylin SB, Herman JG, Versteeg R 2002 Tumor-specific down-regulation of the tumor necrosis factor-related apoptosis-inducing ligand decoy receptors DcR1 and DcR2 is associated with dense promoter hypermethylation. Cancer Res 62:2157-2161

30. Keane MM, Ettenberg SA, Nau MM, Russell EK, Lipkowitz S 1999 Chemotherapy augments TRAIL-induced apoptosis in breast cancer cell lines. Cancer Res 59:734741

31. Mitsiades CS, Treon SP, Mitsiades N, Shima Y, Richardson P, Schlossman R, Hideshima T, Anderson KC 2001 TRAIL/Apo2L ligands selectivity induces apoptosis and overcomes drug resistance in multiple myeloma: therapeutic applications. Blood 98:795-804

32. Orban Z, Mitsiades N, Burke Jr TR, Tsokos M, Chrousos GP 2000 Caffeic acid leukocyte phenethyl ester induces apoptosis, modulates nuclear factor-kappa B and suppresses acute inflammation. Neuroimmunomodulation 7:99-105

33. Barkett M, Gilmore TD 1999 Control of apoptosis by Rel/NF- $\kappa$ B transcription factors. Oncogene 18:6910-6924 
34. Lin YZ, Yao SY, Veach RA, Torgerson TR, Hawiger J 1995 Inhibition of nuclear translocation of transcription factor NF-kappa B by a synthetic peptide containing a cell membrane-permeable motif and nuclear localization sequence. J Biol Chem 270:14255-14258

35. Taylor CC 2000 Platelet-derived growth factor activates porcine thecal cell phosphatidylinositol-3-kinase-Akt/PKB and ras-extracellular signal-regulated kinase-1/2 kinase signaling pathways via the platelet-derived growth factor-beta receptor. Endocrinology 141:1545-1553

36. Datta SR, Dudek H, Tao X, Masters S, Fu H, Gotoh Y, Greenberg ME 1997 Akt phosphorylation of BAD couples survival signals to the cell intrinsic death machinery. Cell 91:231-241

37. Cardone MH, Roy N, Stennicke HR, Salvesen GS, Franke TF, Stanbridge E, Frisch S, Reed JC 1998 Regulation of cell death protease caspase-9 by phosphorylation. Science 282:1318-1321

38. Romashkova JA, Makarov SS 1999 NF-kappaB is a target of AKT in anti-apoptotic PDGF signaling. Nature 401:86-90

39. Ozes ON, Mayo LD, Gustin JA, Pfeffer SR, Pfeffer LM, Donner DB 1999 NF-kappaB activation by tumour necrosis factor requires the Akt serine-threonine kinase. Nature 401:82-85

40. Uno K, Takita J, Yokomori K, Tanaka Y, Ohta S, Shimada H, Floyd H, Sugita K, Abe S, Sako M, Hashizume K, Hayashi Y 2002 Aberrations of the hSNF5/INI1 gene are restricted to malignant rhabdoid tumors or atypical teratoid/rhabdoid tumors in pediatric solid tumors. Genes Chromosomes Cancer 34:33-41

41. Zhao S, Asgary Z, Wang Y, Goodwin R, Andereff M, Younes A 1999 Functional expression of TRAIL by lymphoid and myeloid tumor cells. Br J Haematol 106:827-832

42. Gazitt Y, Shaughnessy P, Montgomery W 1999 Apoptosis-induced by TRAIL and TNF-alpha in human multiple myeloma cells is not blocked by BCL-2. Cytokine 11:1010-1019

43. Gazitt Y 1999 TRAIL is a potent inducer of apoptosis in myeloma cells derived from multiple myeloma patients and is not cytotoxic to hematopoietic stem cells. Leukemia 13:1817-1824

44. Bonavida B, Ng CP, Jazirehi A, Schiller G, Mizutani Y 1999 Selectivity of TRAILmediated apoptosis of cancer cells and synergy with drugs: the trail to non-toxic cancer therapeutics [review]. Int J Oncol 15:793-802

45. Tschopp J, Irmler M, Thome M 1998 Inhibition of fas death signals by FLIPs. Curr Opin Immunol 10:552-558

46. Higuchi H, Bronk SF, Taniai M, Canbay A, Gores GJ 2002 Cholestasis increase tumor necrosis factor-related apoptosis-inducing ligand (TRAIL)-R2/DR5 expression and sensitizes the liver to TRAIL-mediated cytotoxicity. J Pharmacol Exp Ther 303:461-467

47. Wen J, Ramadevi N, Nguyen D, Perkins C, Worthington E, Bhalla K 2000 Antileukemic drugs increase death receptor 5 levels and enhance Apo-2L-induced apoptosis of human acute leukemia cells. Blood 96:3900-3906

48. Zhang X, Franco A, Myers K, Gray C, Nguyen T, Hersey P 1999 Relation of TNF-related apoptosis-inducing ligand (TRAIL) receptor and FLICE-inhibitory protein expression to TRAIL-induced apoptosis of melanoma. Cancer Res 59:2747-2753

49. Pai SI, Wu GS, Ozoren N, Wu L, Jen J, Sidransky D, El-Deiry WS 1998 Rare loss-of-function mutation of death receptor gene in head and neck cancer. Cancer Res $58: 3515-3518$
50. Lee SH, Shin MS, Kim HS, Lee HK, Park WS, Kim SY, Lee JH, Han SY, Park JY, Oh RR, Jang JJ, Han JY, Lee JY, Yoo NJ 1999 Alterations of the DR5/TRAIL receptor 2 gene in non-small cell lung cancers. Cancer Res 59:5683-5686

51. Wu M, Das A, Tan Y, Zhu C, Cui T, Wong MC 2000 Induction of apoptosis in glioma cell lines by TRAIL/Apo-2L. J Neurosci Res 61:464-470

52. Zhang X, Franco AV, Nguyen T, Gray CP, Hersey P 2000 Differential localization and regulation of death and decoy receptors for TNF-related apoptosis-inducing ligand (TRAIL) in human melanoma cells. J Immunol 164:3961-3970

53. Kim K, Fisher MJ, Xu SQ, el-Deiry WS 2000 Molecular determinants of response to TRAIL in killing of normal and cancer cells. Clin Cancer Res 6:335-346

54. Wu GS, Burns TF, McDonald III ER, Jiang W, Meng R, Krantz ID, Kao G, Gan DD, Zhou JY, Muschel R, Hamilton SR, Spinner NB, Markowitz S, Wu G, el-Deiry WS 1997 KILLER/DR5 is a DNA damage-inducible p53-regulated receptor gene. Nat Genet 17:141-143

55. Sheikh MS, Burns TF, Huang Y, Wu GS, Amundson S, Brooks KS, Fornace Jr AJ, el-Deiry WS 1998 p53-dependent and -independent regulation of the death receptor KILLER/DR5 gene expression in response to genotoxic stress and tumor necrosis factor alpha. Cancer Res 58:1593-1598

56. Nagane M, Pan G, Weddle JJ, Dixit VM, Cavenee WK, Huang HJ 2000 Increased death receptor 5 expression by chemotherapeutic agents in human gliomas causes synergistic cytotoxicity with tumor necrosis factor-related apoptosis-inducing ligand in vitro and in vivo. Cancer Res 60:847-856

57. Gibson SB, Oyer R, Spalding AC, Anderson SM, Johnson GL 2000 Increased expression of death receptor 4 and 5 synergized the apoptosis response to combined treatment with etoposide and TRAIL. Mol Cell Biol 20:205-212

58. Degli-Esposti MA, Dougall WC, Smolak PJ, Waugh JY, Smith CA, Goodwin RG 1997 The novel receptor TRAIL-R4 induces NF-kappa B and protects against TRAIL-mediated apoptosis, yet retains an incomplete death domain. Immunity 7:818-820

59. Schneider P, Thome M, Burns K, Bodmer JL, Hofmann K, Kataoka T, Holler N, Tschopp J 1997 TRAIL receptors 1 (DR4) and 2 (DR5) signal FADD-dependent apoptosis and activate NF-kappa B. Immunity 7:831-836

60. Lin Y, Devin A, Cook A, Keane MM, Kelliher M, Lipkowitz S, Liu ZG 2000 The death domain kinase RIP is essential for TRAIL (Apo2L)-induced activation of Ikappa B kinase and c-Jun N-terminal kinase. Mol Cell Biol 20:6638-6645

61. Oya M, Ohtsubo M, Takayanagi A, Tachibana M, Shimizu N, Murai M 2001 Constitutive activation of nuclear factor-kappaB prevents TRAIL-induced apoptosis in renal cancer cells. Oncogene 20:3888-3896

62. Keane MM, Rubinstein Y, Cuello M, Ettenberg SA, Banerjee P, Nau MM, Lipkowitz S 2000 Inhibition of NF-kappaB activity enhances TRAIL-mediated apoptosis in breast cancer cell lines. Breast Cancer Res Treat 64: 211-219

63. Chen X, Thakkar H, Tyan F, Gim S, Robinson H, Lee C, Pandey SK, Nwokorie C, Onwudiwe N, Srivastava RK 2001 Constitutively active Akt is an important regulator of TRAIL sensitivity in prostate cancer. Oncogene 42:6073-6083

64. Nesterov A, Lu X, Johnson M, Miller GJ, Ivashchenko Y, Kraft AS 2001 Elevated AKT activity protects the prostate cancer cell line LNCaP from TRAIL-induced apoptosis. J Biol Chem 276: 10767-10774 